\title{
5 \\ Fate of Pathogens in Stormwater Plumes
}

\author{
Alex McCorquodale, Susanne Carnelos, loannis Georgiou, Donald \\ Barbé, Gianna Cothren, A. J. Englande,
}

Modern tools for management of recreational waters include field monitoring, laboratory analyses and computer modeling. A case study of a brackish receiving water body subjected to periodic discharges of contaminated stormwater runoff is presented to illustrate the field and laboratory support that is needed to develop a numerical model. Field sampling protocols and laboratory procedures are outlined and the results are presented in the form required for a numerical model. Results conclusively showed that pathogen counts are strongly correlated to storm-generated flows. It was also found that fine sediment is a significant transporting medium for pathogen indicators. A discussion of the implications of these studies on numerical modeling is presented. A simple dilution model is introduced as a screening level model for shoreline contamination due to attached plumes from relatively wide storm drainage canals.

\subsection{Introduction}

Recreational waters of many large cities in the United States and Canada are severely impaired by pathogens in storm water runoff. The source of these pathogens is often from combined sewer overflows (CSOs) or cross-flows due to surcharging of sanitary sewers in separated systems. Indicator bacterial

McCorquodale, J., S. Carnelos, I. Georgiou, D.E. Barbe, G. Cothren and A.J. Englande. 2004. "Fate of Pathogens in Stormwater Plumes." Journal of Water Management Modeling R220-05. doi: 10.14796/JWMM.R220-05.

(C) CHI 2004 www.chijournal.org ISSN: 2292-6062 (Formerly in Innovative Modeling of

Urban Water Systems. ISBN: 0-9683681-9-0) 
groups such as fecal coliform (FC), E. Coli and Enterococci are used to determine the potential presence of pathogens when evaluating risk to bathers. Coliform bacteria groups are often used as indicators because they are easily detectable using simple laboratory tests, generally not found in unpolluted waters and the number of indicator bacteria tends to be correlated with the extent of contamination. FC bacteria are indicators for organisms from the intestinal tract of humans and other animals. Although FC is currently the most commonly used indicator group for regulatory purposes when dealing with primary contact recreation, there are questions regarding its suitability as a pathogen indicator. The U.S. Environmental Protection Agency (EPA) stated that $E$. Coli bacteria is a better pathogen indicator for freshwater and Enterococci bacteria is better for brackish waters (EPA, 1986). Jin et al. (2000) statistically analyzed field data for urban runoff discharges to Lake Pontchartrain in Louisiana following rainfall events and concluded that Enterococci is a more reliable and sensitive indicator for brackish water. In the laboratory Enterococci is a single class of microbe while fecal coliform is a mix of different microbes which vary from sample to sample; thus it is easier to conduct controlled experiments on Enterococci than on the broader fecal coliform group of bacteria. Consequently, for better consistency and as a possible future indicator, it was decided that Enterococci should be part of this study.

One of the problems with managing recreational waters is that laboratory analysis to measure indicators is a 48 - $\mathrm{h}$ process that provides only a two-day old "snapshot" of the water quality. Since the indicator bacteria have die-off rates that depend on water parameters such as salinity and temperature and the stormwater runoff discharges have variable travel speeds and migration patterns dependent on the receiving water body, these "snapshots" are rarely representative of the environment when the data are reported. A forecasting model would allow for more qualified decisions to be made regarding the safety of recreational waters.

The fate of urban stormwater runoff from the New Orleans metropolitan area discharged to the south shore of Lake Pontchartrain in Louisiana is used as a case study. Historically, Lake Pontchartrain has provided valuable recreational opportunities for residents of New Orleans and surrounding areas. However, the Louisiana Department of Health and Hospitals (LDHH) issued an advisory in 1985 to discourage swimming in Lake Pontchartrain because the concentrations of FC bacteria regularly exceeded the State water quality standards for primary contact recreation (Louisiana Department of Health and Human Resources, 1982). Although this advisory is still in effect for the south shore, some swimming activity is occurring. 
Since the average elevation in New Orleans is several feet below sea level, levees have been constructed to protect the city from flooding. Most stormwater runoff must be pumped to Lake Pontchartrain via drainage canals. The drainage system, operated and maintained by the Sewerage and Water Board of New Orleans (SWB), has a pumping capacity of over 120 billion liters per day. The system is designed to handle about $25 \mathrm{~mm}$ of rain in the first hour and about 12 $\mathrm{mm}$ per hour thereafter (SWB, 1990). Although the sanitary and stormwater sewer systems in New Orleans are separate, age and high subsidence rates in the area result in damaged pipes that allow cross-flow and contamination of the storm runoff. The urban stormwater contains: pathogens (e.g. FC), nutrients, organic material, suspended solids and toxic compounds (heavy metals and pesticides) (Yu, 1995).

Since the stormwater runoff has a freshwater density and the lake water is typically brackish, the discharges usually behave as surface-buoyant plumes. Characteristics of these types of plumes include: movement and spreading initially confined to the surface layers of the water column, increased lateral spreading, and modified mixing and dilution processes. In addition, the combination of low-velocity stormwater discharges and the alongshore currents of the receiving waters often results in narrow, shore-hugging outfall plumes with impaired spreading and dilution. Figure 5.1 is an aerial photograph

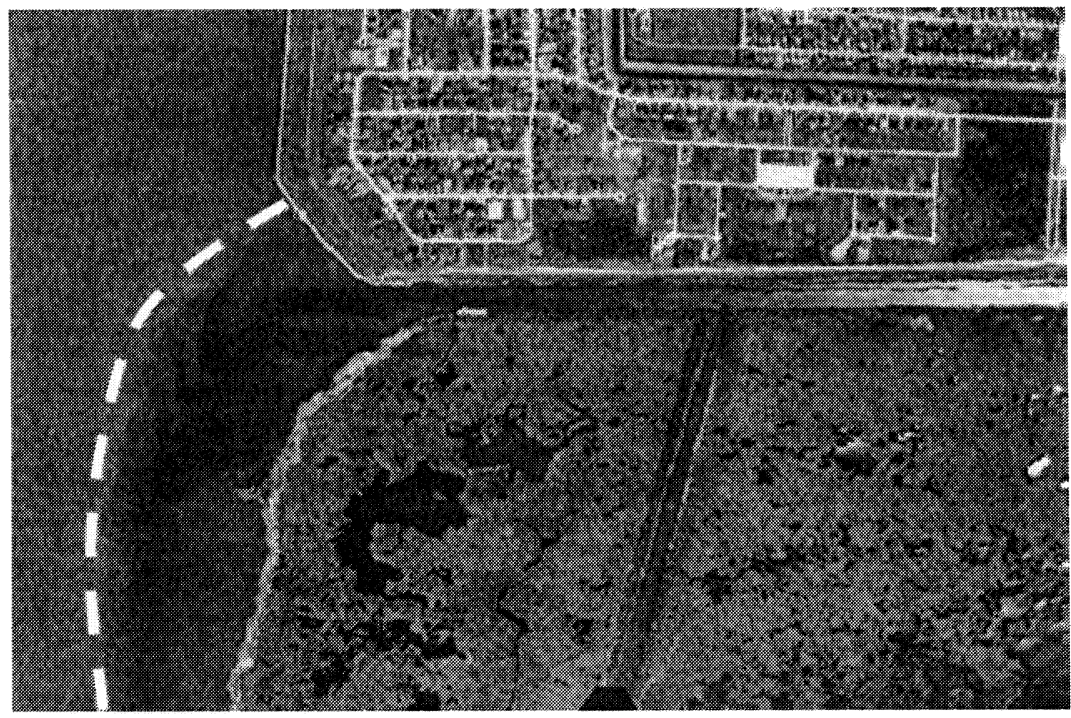

Figure 5.1 Aerial photograph showing typical outfall plume behaviour (Courtesy of Jefferson Parish). 
of a stormwater runoff discharge to Lake Pontchartrain that is representative of the plume behaviour observed in the south shore of the lake.

An urban stormwater study along the south shore of Lake Pontchartrain was conducted by a research team from the University of New Orleans (UNO) and Tulane University. The research comprised a field studies component as well as a numerical modeling component. The overall objective was to develop a program for managing safe primary contact use of the lake's recreational waters at public beaches and shoreline parks. This plan would include an earlywarning forecasting model that will estimate the immediate and short-term risk of exceeding pathogen indicator concentration criteria in recreational areas of Lake Pontchartrain based on hydrologic and climatic data. This chapter describes the field studies to support the modeling as well as a simplified dilution decay model.

The numerical modeling component consisted of the development of a hydrodynamic fate and transport model for this purpose. The model, based on a modification of the Princeton Ocean Model (Blumberg and Mellor, 1987), incorporates the site-specific response to tides and climate and predicts the trajectory of the stormwater plumes and the associated bacteria concentration fields. This is a three-dimensional model that includes density currents due to temperature and salinity. The forecasting system consists of the hydrodynamic component and integrated bacteria fate/transport sub-models based on six years of field data, laboratory analyses and experiments.

The field studies consisted of: (i) a shoreline water quality study, (ii) a plume tracking study and (iii) a laboratory study. Each of these studies are discussed below in greater detail.

Specific objectives of the research included:

- collection of field data to determine the current state of water quality in the south shore area;

- collection of field data to characterize stormwater plumes resulting from storm-induced pumped discharges in terms of plume trajectory, shape and bacteria concentration field;

- collection of field data within the urban drainage canals to characterize stormwater bacteria loading;

- development of the 3-D hydrodynamic fate and transport model through modification of the Princeton Ocean Model (POM); and

- development of a pathogen sub-model in the modified POM model.

This chapter deals with the first three objectives. 


\subsection{Description of Study Area}

As shown in Figure 5.2, Lake Pontchartrain is part of the Pontchartrain Estuary and consists of three lakes: Maurepas, Borgne and Pontchartrain. Lake Pontchartrain is located in southeast Louisiana and forms the northern boundary of the City of New Orleans. The lake is approximately $1660 \mathrm{~km}^{2}$ in area, has an average depth of 3.6 to $4.6 \mathrm{~m}$ and drains a watershed approximately $12,200 \mathrm{~km}^{2}$ in area. Salty water from the Gulf of Mexico enters Lake Pontchartrain through two tidal passes (The Rigolets and Chef Menteur) as well as the Inner Harbor Navigation Canal (IHNC), which connects the lake to the Gulf of Mexico through the Mississippi River Gulf Outlet (MRGO). There are also freshwater inputs such as Mississippi River floodwater diversions and runoff from rural and urban watersheds through several river systems and local streams. Typical salinities in the lake system vary from $1 \mathrm{ppt}$ in the west to $6 \mathrm{ppt}$ in the east. The diurnal tide has a range of 100 to $150 \mathrm{~mm}$. The lake circulation patterns are strongly wind-driven with tidal effects near the passes.

The study area (shown in Figure 5.2) extends along the south shore of Lake Pontchartrain in Orleans Parish, Louisiana from east of the Lakefront Airport to west of the $17^{\text {th }}$ Street urban drainage canal. Recreational waters in

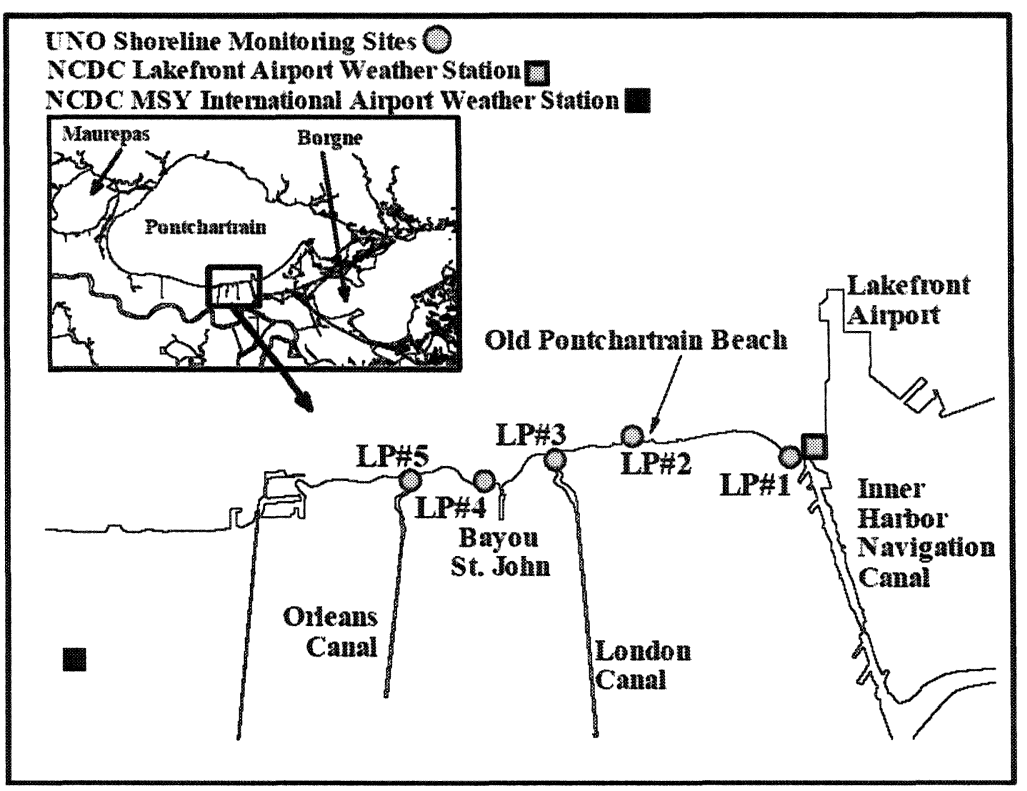

Figure 5.2 Field location map (inset) and field monitoring site map. 
the study area are directly affected by two urban stormwater drainage canals, the London and Orleans Canals. The five monitoring sites selected for the water quality shoreline study are shown in Figure 5.2. All of these sites are characterized by past or present primary and secondary contact recreational usage in an area where the LDHH swimming advisory is in effect. Two of the sites are located at the outlets of urban runoff drainage canals. The other sites are located in fairly close proximity to canals and are beach or recreational park areas. The sites and points of collection are as follows:

- LP\#1 is a beach area with a small boat launch near the outlet of the IHNC. The samples were collected from the boat launch.

- LP\#2 is a beach area with a series of jetties west of LP\#1 and is located approximately midway between LP\#1 and LP\#3. This area is the former site of the Pontchartrain Beach Amusement Park. The samples were collected from the west side of the east jetties.

- LP\#3 is located at the mouth of the London Outfall Canal. The samples were collected from the Lakeshore Drive bridge crossing the canal.

- LP\#4 is the Old Beach recreational park area between LP\#3 and LP\#5 near the mouth of Bayou St. John. The samples were collected from the lake seawall bordering this area.

- LP\#5 is located at the mouth of the Orleans Outfall Canal. The samples were collected from the Lakeshore Drive bridge crossing the canal.

The plume tracking studies were performed at the London and Orleans Canals and the surrounding impacted areas during stormwater pump events.

\subsection{Field Studies Methodology}

\subsubsection{Shoreline Water Quality Study}

Water quality monitoring was performed at the sampling locations in Figure 5.2. The primary water quality parameter was FC bacteria which is the indicator used by the State (Louisiana Department of Environmental Quality, 1999). Other parameters were: salinity, conductivity, water temperature, total nitrogen (N) as nitrite/nitrate $\left(\mathrm{NO}_{2}{ }^{-} / \mathrm{NO}_{3}{ }^{-}\right)$, ammonia $\left(\mathrm{NH}_{3}\right)$, total Kjeldahl nitrogen (TKN), ortho-phosphate (ortho- $\mathrm{PO}_{4}{ }^{3-}$ ), total phosphorus (P), total suspended 
solids (TSS), volatile suspended solids (VSS) and pH. A minimum of 5 samples were collected per 30-d period at each site as required by the Louisiana Department of Environmental Quality (LDEQ). Both wet and dry weather data were obtained.

FC grab samples were collected in sterilized Nasco Whirl-Pak Thio-Bags containing sodium thiosulfate tablets for sample preservation. Samples were taken within $0.3 \mathrm{~m}$ of the water surface. A small air space was left in each bag. The samples were stored and transported in an ice chest to be analyzed at the LDHH Water Laboratory within four hours of sample collection using the Multiple Tube Fermentation Technique as outlined in Method 9221A of Standard Methods for the Examination of Water and Wastewater (American Public Health Association (APHA), 1998). In situ salinity, conductivity and water temperature measurements were taken using a hand-held YSI 85 S-CDO-T meter at the time of sample collection. The remaining parameters were measured by collecting additional grab samples at each site using a Wildco Water Bottle Kit manual sampler and a manual Swing Sampler. These samples were analyzed by the UNO Environmental Engineering Laboratory to determine the following parameters by the following APHA (1998) methods:

- nitrogen as ammonia, Phenate Method (Method 4500- $\mathrm{NH}_{3} \mathrm{E}$ );

- total nitrogen as nitrites/nitrates, Cadmium Reduction Method (Method 4500- $\mathrm{NO}_{3}{ }^{-} \mathrm{E}$ );

- total phosphorus, Acid Persulfate Digestion/Ascorbic Acid Method (Method 4500-P B,E);

- phosphorus as ortho-phosphate, Ascorbic Acid Method (Method 4500-P E);

- total suspended solids, Filtration-Evaporation-Drying-Gravimetric Method (Method 2540 B);

- volatile suspended solids, Combustion and Gravimetric method (Method $2540 \mathrm{E}$ );

- $\mathrm{pH}$, Hach $\mathrm{pH}$ meter (Method 4500- $\mathrm{H}^{+}$).

The collection, preservation and storage of all samples was performed according to the requirements outlined in Standard Methods for the Examination of Water and Wastewater (APHA, 1998). All analyses were performed within the allowable storage period given in Standard Methods for the Examination of Water and Wastewater (APHA, 1998).

Hourly rainfall data over the study period were also collected from the National Climatic Data Center (NCDC) website for the NCDC Lakefront Airport weather station (shown in Figure 5.2) located near the study area. 


\subsubsection{Plume Tracking Study}

Field data were collected to provide information on plume migration during actual stormwater runoff pump events through drifter tracking studies. The rainfall events sampled were generally greater than $25 \mathrm{~mm}$ with a dry period of at least three days preceding the event. An Argos buoyant GPS drifter was deployed at the mouth of a drainage canal upon notification of a pumping event by SWB. The Argos Drifter is a free-drifting buoy used for acquiring position. During each event, the latitude and longitude coordinates of the drifter location were transmitted at regular intervals thereby tracking the path of the plume. The GPS receiver acquires the position and transmits the data by an Argos Platform Transmitting Terminal (PTT). The track coordinates were plotted during each event and the drifter was retrieved by boat using GPS equipment following the event.

Water quality monitoring in the area of the plumes was performed concurrently with the drifter studies. A 25 -station grid with a $150 \mathrm{~m}$ mesh was generated and centered on the most recent drifter position. The parameters measured at each location on the grid were: E. Coli, Enterococci, FC, salinity, conductivity, temperature, Secchi disk transparency and dissolved oxygen. Sampling was repeated on consecutive days following a storm event until background conditions were detected within the 25-station moving grid. Background data for the receiving waters were obtained through bi-monthly monitoring of the abovementioned parameters during dry weather periods. Figure 5.3 shows the grid as it would be positioned at London Canal on the first day of monitoring or for background water quality characterization.

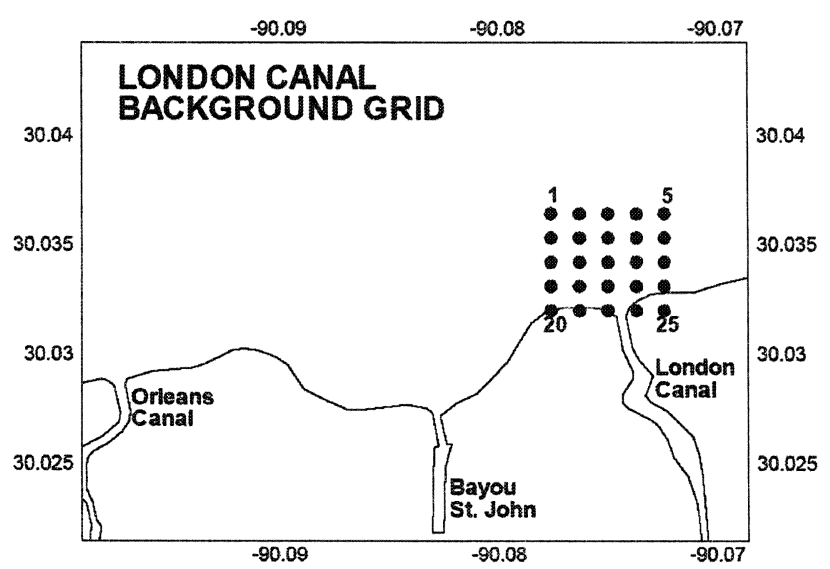

Figure 5.3 25-station plume monitoring grid used during drifter studies. 
All microbiological samples were collected manually in sterile sampling bottles as recommended in the Standard Methods for the Examination of Water and Waste Water. Samples were collected at $0.3 \mathrm{~m}$ and handled by the same procedure as the shore samples. FC, E. Coli and Enterococci were enumerated using the Multiple Tube Method and Quanti-Tray ${ }^{\mathrm{TM}}$ Method according to the procedures outlined by the American Public Health Association (1998) and IDEXX (1993), respectively. Both positive and negative control organisms for each analytical procedure validated the analyses used. Secchi disk transparency, conductivity, dissolved oxygen and temperature were measured in-situ. Samples to be analyzed for $\mathrm{pH}$, salinity and turbidity were transported in an ice chest to the Tulane laboratories. Methods of measurement/analysis for the nonmicrobiological parameters and the required equipment are summarized as follows:

- Dissolved oxygen: Method 4500-OG with YSI 55 Dissolved Oxygen Meter ( 0 - $20 \mathrm{mg} / 1$ with $\pm 0.3 \mathrm{mg} / 1$ accuracy);

- $\mathrm{pH}$ : Method $4500-\mathrm{H}^{+}$with Orion combination $\mathrm{pH}$ electrode BNC model H-05711-41 and Orion EA 940 ion analyzer $( \pm 0.2 \mathrm{pH}$ units accuracy);

- Secchi disk transparency: Preisendorfer 1986 with LaMotte Secchi Disc, sounding lead and calibrated line;

- Turbidity: Method 2130B with LaMotte Digital Turbidity Meter Model 2008 ( $0.2 \%$ accuracy or \pm 0.05 NTUs);

- Salinity: Method 2520B with YSI30 Portable ConductivityMeter (0 - 80 ppt with $1.0 \%$ accuracy (full scale));

- Conductivity: Method 2510B with YSI 30 Portable Conductivity Meter (0 to $4,999 \mu \mathrm{S} / \mathrm{cm}, \pm 0.5 \%$ accuracy (full scale));

- Temperature: Method 2550B with YSI 55 Dissolved Oxygen Meter $\left(-5^{\circ} \mathrm{C}\right.$ to $+45^{\circ} \mathrm{C}$ with $0.1^{\circ} \mathrm{C}$ accuracy).

\subsubsection{Laboratory Study}

Laboratory studies were performed to determine the kinetics of the bacterial indicators in the water column as well as in the lake bottom sediments. Also, the relationships of the inactivation rates to various environmental factors were investigated. The most important environmental factors influencing the fate of FC, Enterococci and E. Coli are light intensity (Litved and Landfald, 2000), salinity (Yang, 2000), and temperature (El-Sharkawi et al., 1989). Field conditions were simulated and temperature, salinity and light intensity were 
varied so that the effects of these parameters on the water column die-off rates could be investigated. A sedimentation study was also conducted to determine the rate of reduction of bacteria from the water column due to the settling of suspended solids to which the bacteria have become adhered.

For the water column bacterial kinetics studies, stormwater and brackish lake water were mixed in varying ratios to obtain test water with salinities of 3 , 6, 9 and 12 ppt. Experiments were conducted under light levels of 5,000, $10,000,20,000$, and 50,000 lux as well as in the absence of light. The stormwater-brackish lake water mixtures were inoculated with $E$. Coli and Enterococci at levels of $10^{3} \mathrm{MPN} / 100 \mathrm{ml}$ and then analyzed to determine the initial microbial concentrations. E. Coli and Enterococci were enumerated using the Multiple Tube Fermentation and Quanti-Tray ${ }^{\mathrm{TM}}$ Methods (APHA, 1998 and IDEXX, 1993). The samples to be exposed to varying light intensities were placed in open-topped water baths with pre-set temperature levels of 20 , 25,30 , and $35^{\circ} \mathrm{C}$. For the absence of light case, the tests were carried out in enclosed water baths pre-set to the desired temperatures. Each experiment was carried out from 3 to 4 days depending on the microbial inactivation rate.

The die-off of Enterococci in three different sediment types was investigated in the laboratory-based sediment study. Sediment samples were collected from three locations in Lake Pontchartrain: the mouth of London Canal, between the London Canal and Pontchartrain Beach (open-lake), and Pontchartrain Beach. The locations were chosen since they yielded samples with various organic contents, particle size distributions, and nutrient contents that may influence die-off of indicator bacteria. Also, the locations represent the path of bacterial pathogens as they exit London Canal following a rain event. The lake sediment analyses included: cation exchange capacity (CEC) (EPA, 1986), particle size distribution, total organic carbon (TOC) (APHA, 1998), total Kjeldahl nitrogen (TKN) (APHA, 1998), and total and volatile suspended solids (TSS and VSS) (APHA, 1998). Microcosms were prepared using 200-gram samples of the sediment in $2 \mathrm{~L}$ autoclaved glass bottles. Autoclaved lake water adjusted to the lake salinity (6ppt) was added to bring the total volumes to one liter. All bottles were kept at room temperature (about $24^{\circ} \mathrm{C}$ ). The sediment was inoculated with Enterococcus faecealis and incubated with the appropriate agar. Beginning one hour after inoculation, sediment samples were taken over a 9week period from the bottles containing the three sediment types as well as one control and the bacteria were quantified. Identical amounts of sediment were removed from the bottle to measure TSS. This procedure was conducted at $5 \mathrm{~d}$ intervals or until die-off occurred. Once die-off was initiated, three additional samples were taken to obtain a die-off curve. 
The sedimentation study was conducted in three parts. The analyses for characterization of the suspended particles included: salinity, turbidity, particle size distribution, TSS and VSS, settleable solids (APHA, 1998) and magnesium and calcium concentrations (EPA, 1986). Also, static settling tests were conducted. Samples of undiluted stormwater were collected from the mouth of an urban drainage canal to assess the microbial distribution in the water column. Microbial samples were taken at time zero from fresh homogenized stormwater samples. After leaving the samples covered and quiescent for five hours, the upper layers were siphoned off. Composite samples of the siphoned portions and bottom sediment samples were collected and analyzed for $E$. Coli and Enterococci. Finally, fractional filtration was performed to determine the distribution of microbial indicators on the various suspended particles. Measured volumes of stormwater samples were passed through a series of screen filters $(100-\mu \mathrm{m}, 50-\mu \mathrm{m}, 35-\mu \mathrm{m}, 5-\mu \mathrm{m}$ and $0.45-\mu \mathrm{m})$. Suspension solutions of each particle size range were then analyzed for E. Coli and Enterococci.

\subsection{Field Studies Results}

\subsubsection{Shoreline Water Quality Study}

Statistical evidence was found that urban stormwater discharges are indeed a significant source of pathogens and that elevated bacteria levels are definitely correlated with rainfall events sufficient to initiate stormwater pumping at four of the five sites. The exception is the site near the IHNC where there appears to be an active, continuous source that has not been identified. Of the remaining four sites, non-compliance with LDEQ surface water quality regulations for FC exceeded 50\% except at Old Beach near Bayou St. John. Table 5.1 shows the non-compliance observed over the study period and the t-test probabilities that FC is weather-dependent for the five shoreline sites. FC probability plots provided estimates of the risk of exceeding a given bacteria level at any one of the five sites under wet and/or dry weather conditions. Figure 5.4 indicates the chance of encountering FC levels above $200 \mathrm{MPN} / 100 \mathrm{~mL}$ at each site during the primary contact recreational season. Nutrient and suspended solids levels were higher when FC levels were elevated. Figure 5.5 shows the wet and dry weather averages for FC, dissolved inorganic nitrogen (DIN) and TSS. This supports the theory that the stormwater is contaminated by sanitary sewer cross-flows. Recreational sites adjacent to drainage canals were impacted by stormwater discharges depending on which direction the plume was driven by 
Table 5.1 t-Test probability that FC is dependent on significant rainfall events and \% of time non-compliance with LDEQ Surface Water Quality Regulations (Section LAC 33:IX.1113.C.5.b) was observed.

\begin{tabular}{ccc}
\hline Site & $\begin{array}{c}\text { \% Probability of "Wet” Weather } \\
\text { Dependency }\end{array}$ & $\begin{array}{c}\text { \% Non-Compliance } \\
\text { (LDEQ Regs.) }\end{array}$ \\
\hline LP\#1 & 66.36 & 47 \\
LP\#2 & 98.43 & 53 \\
LP\#3 & 99.99 & 59 \\
LP\#4 & 99.46 & 28 \\
LP\#5 & 99.99 & 72 \\
\hline
\end{tabular}

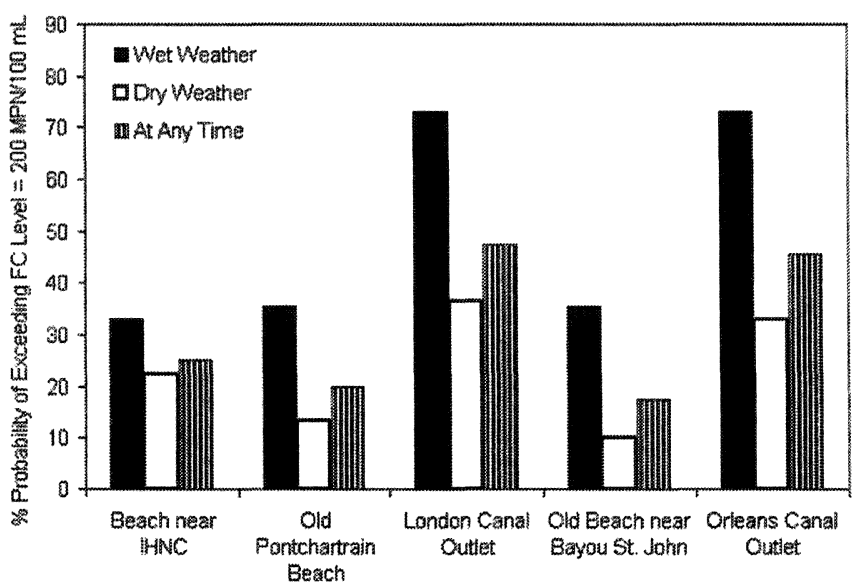

Figure 5.4 Probability of exceeding a FC concentration of $200 \mathrm{MPN} / 100 \mathrm{~mL}$ during the primary contact recreation season.

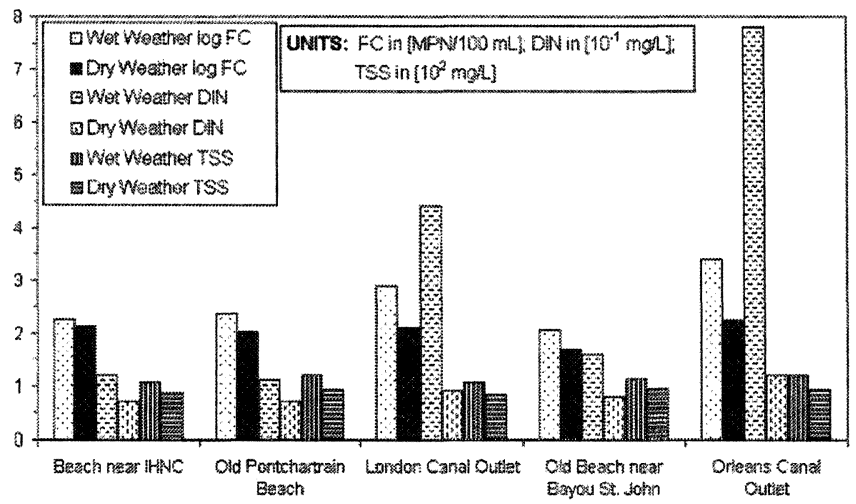

Figure 5.5 Comparison of wet and dry data averages over study period for water quality indicators (Note: fecal coliform is in log units). 
the lake circulation. Overall, the south shore recreational waters in this area are still often unsuitable for primary contact activities, particularly for the two or three day period following significant storm events $(>12 \mathrm{~mm})$.

\subsubsection{Plume Tracking Study}

Several stormwater runoff pumping events were studied during the plumetracking component. Plume migration behaviour was observed for a variety of wind and tide conditions and storm intensities. Six pump events were captured for which water quality characterization of the plumes was accomplished through the grid monitoring in addition to characterization of the source through the in-canal monitoring. The bi-monthly background grid monitoring provided information on typical water quality conditions existing in the ambient receiving waters prior to a stormwater discharge event.

The drifter studies also verified that the plume impact zone is highly sensitive to wind. Analysis of the FC data indicated a dilution of 3 to 6 within a distance of 30 canal widths from the point of discharge. Figure 5.6 shows the migration of two stormwater plumes tracked by the buoyant drifter as well as wind vector plots for both tracking periods. Also illustrated in the figure is the

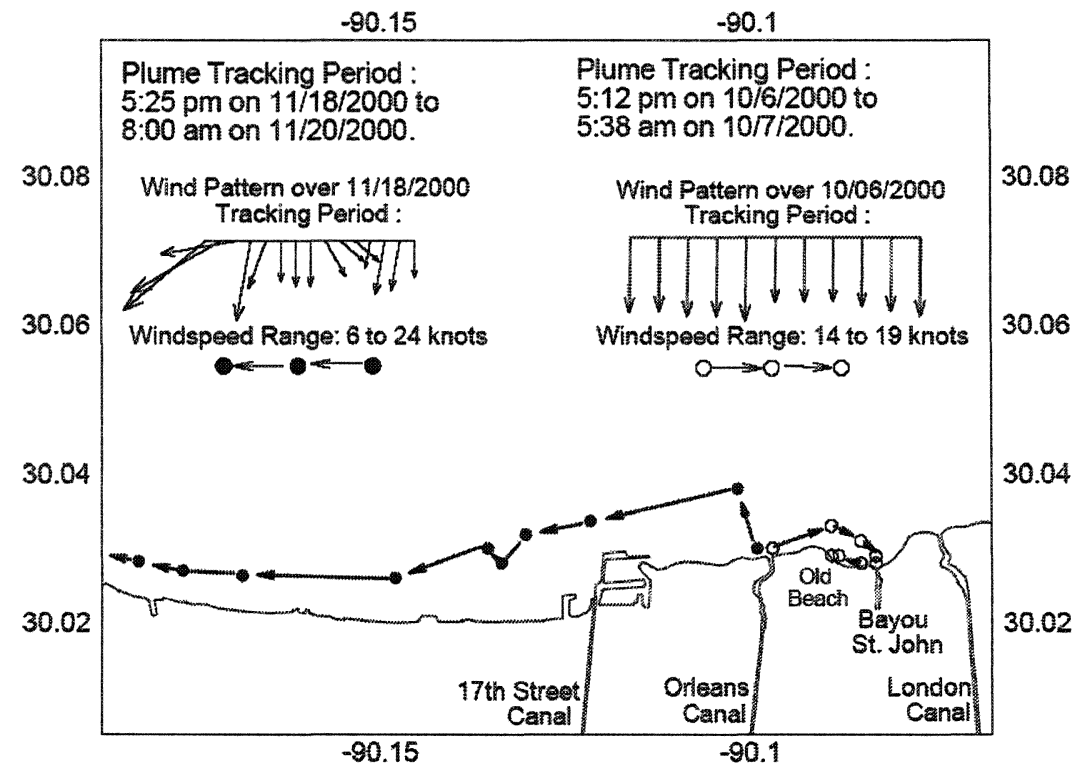

Figure 5.6 Examples of stormwater plumes tracked using the buoyant GPS drifter. 


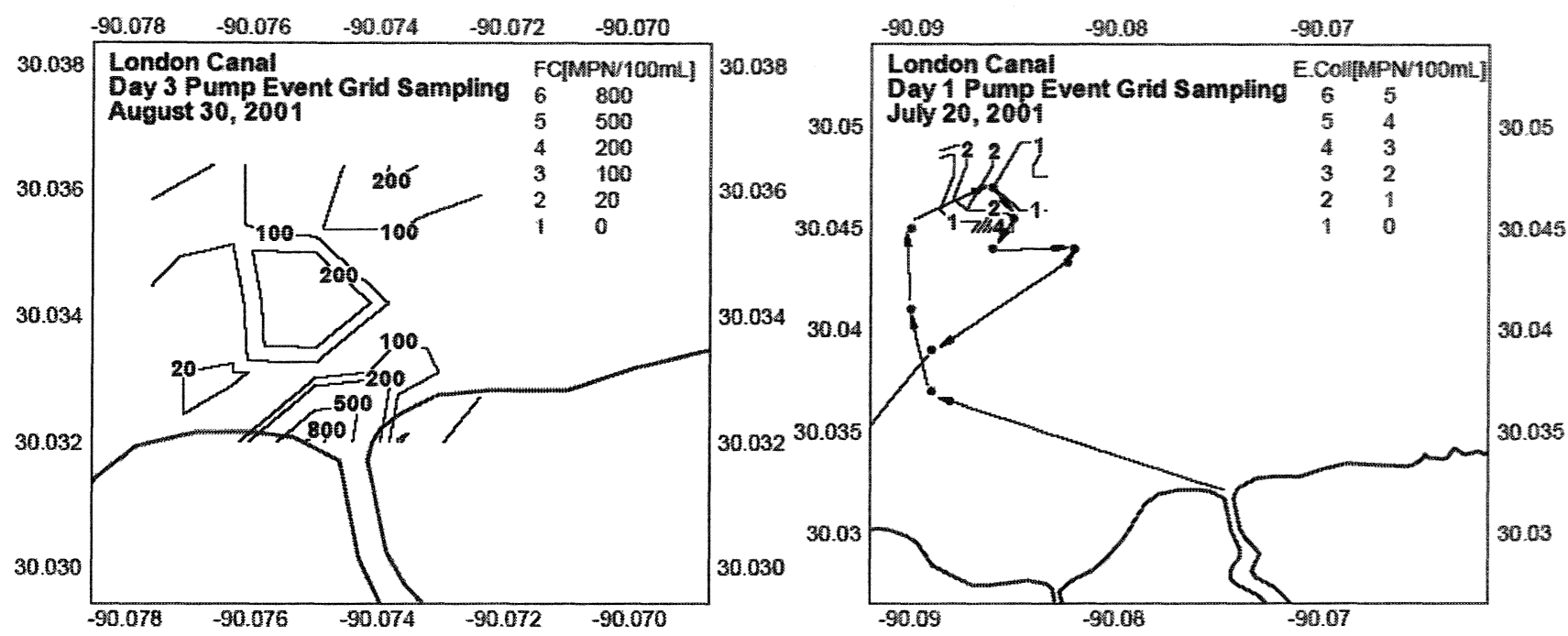

Figure 5.7 FC plume measured using the stationary background grid (at left); E. Coli plume measured using the moving grid (at right). 
high variability in plume migration patterns in the study area and the potential for impacting nearby recreational waters. Figure 5.7 shows a FC plume measured using the background grid as well as a migrating E. Coli plume as measured using the moving grid.

\subsubsection{Laboratory Study}

The laboratory studies showed that E. Coli is less saline-tolerant and more sensitive to light exposure than Enterococci under simulated field conditions. In addition, the reduction rate of $E$. Coli from the water column due to settling of suspended particles to which the organisms adhere was nearly double that of Enterococci. These results support the theory that Enterococci may be a more suitable indicator for brackish water bodies such as Lake Pontchartrain. Table 5.2 summarizes some of the laboratory study results concerning the effect of certain environmental factors on the inactivation rates for $E$. Coli and Enterococci.

The field data and laboratory study results also indicated that the bacteria die-off rates follow first-order kinetics. Using the data obtained for Enterococci, equations describing the relationships of the inactivation rates to salinity, water temperature, light intensity and settling loss were developed. These equations can be used to compute the amount of decay that can be expected when stormwater is discharged to the lake. The data showed that the effect of salinity on the rate constant is site-specific and can be represented by a quadratic equation. The effect of temperature on the rate constant could not be quantified without the influence of the other environmental factors. A widely used equation for temperature presented by Thomann and Mueller (1987) (Equation 5.1) was modified to incorporate the effects of the four environmental factors on the overall inactivation rate (Equation 5.2).

where:

$$
\begin{aligned}
k_{T} & =k_{20}(1.07)^{T-20} \\
k & =1.07^{(T-20)} \cdot\left(k_{S}+k_{P}+k_{L}\right)
\end{aligned}
$$

$k_{T}=$ rate constant as a function of temperature in $\mathrm{h}^{-1}$,

$T=$ temperature in degrees Celsius,

$k_{20}=$ inactivation rate constant at 20 degrees Celsius and has a value of $0.07 \mathrm{~h}^{-1}$,

$k_{S}=$ effect of salinity on the rate constant (at 20 degrees Celsius) in $\mathrm{h}^{-1}$, 
Table 5.2 Laboratory analysis data for effects of environmental factors and sedimentation loss on overall inactivation rate constant, k, for E. Coli and Enterococci.

\begin{tabular}{|c|c|c|c|c|c|c|c|c|}
\hline \multirow{2}{*}{$\begin{array}{l}\text { Salinity } \\
\text { [ppt] }\end{array}$} & \multicolumn{2}{|c|}{$\mathrm{k}\left[\mathrm{h}^{-1}\right]$} & \multirow{2}{*}{$\begin{array}{c}\text { Water } \\
\text { Temp. }\left[{ }^{\circ} \mathrm{C}\right]\end{array}$} & \multicolumn{2}{|c|}{$\mathrm{k}\left[\mathrm{h}^{-1}\right]$} & \multirow{2}{*}{$\begin{array}{l}\text { Light Intensity } \\
\text { [lux] }\end{array}$} & \multicolumn{2}{|c|}{$\mathrm{k}\left[\mathrm{h}^{-1}\right]$} \\
\hline & E.Coli & Enterococci & & E.Coli & Enterococci & & E.Coli & Enterococci \\
\hline 3 & 0.040 & 0.039 & 20 & 0.078 & 0.070 & 0 & 0.040 & 0.039 \\
\hline 6 & 0.060 & 0.057 & 25 & 0.058 & 0.058 & 10,000 & 0.075 & 0.070 \\
\hline 9 & 0.082 & 0.078 & 30 & 0.068 & 0.061 & 20,000 & 0.094 & 0.090 \\
\hline 12 & 0.123 & 0.090 & 35 & 0.092 & 0.074 & 50,000 & 0.134 & 0.116 \\
\hline \multicolumn{7}{|c|}{ Loss Due to Sedimentation } & E. Coli & Enterococci \\
\hline \multicolumn{7}{|c|}{ Fraction of bacteria attached to suspended solids, $F_{P}$} & 0.27 & 0.09 \\
\hline \multicolumn{7}{|c|}{ Settling velocity (weighted avg. for SS size), Vs $\left[\mathrm{m} \mathrm{h}^{-1}\right]$ (Stokes' Law) } & 0.27 & 0.4 \\
\hline \multicolumn{7}{|c|}{ Constant for particle shape effect, ? } & 1 & 1 \\
\hline \multicolumn{7}{|c|}{ Inactivation rate due to settling, $\mathrm{k}_{\mathrm{P}}\left[\mathrm{h}^{-1}\right]$} & $0.07 / \mathrm{H}$ & $0.04 / \mathrm{H}$ \\
\hline
\end{tabular}

*Note: $\mathrm{H}$ is the water depth [m]. 


$$
\begin{aligned}
& k_{P}=\text { inactivation rate (at } 20 \text { degrees Celsius) due to settling } \\
& \text { of the suspended particles in } \mathrm{h}^{-1} \\
& k_{L}=\text { effect of light intensity on the overall inactivation rate }
\end{aligned}
$$

The sediment study showed that canal sediment has the highest content of organics and nutrients and the smallest particle size distribution while the beach sediment had the lowest organic and nutrient content and largest particle size distribution. In addition, the canal sediment was very sandy ( $82.5 \%$ sand) and appeared to be poorly graded, or well sorted. The open-lake sediment was well graded, or poorly sorted, and had a widely distributed particle size distribution with nearly equal parts sand, silt and clay. The beach sediment was sand. The canal sediment had the highest CEC while the beach sample had the lowest. The open-lake sediment consistently exhibited characteristics between the beach and canal sediments.

In terms of die-off, the sediment study showed the beach sediment represented the most suitable environment for sustained Enterococci life, since it exhibited the highest concentration of bacteria and was characterized by the smallest decay rate. The second lowest decay rate constant was found with the open-lake sediment. The open-lake sediment had a lower bacteria concentration than the canal sediment but die-off appeared to begin sooner than the canal or beach sediment. The most rapid die-off was observed in the canal sediment. The data indicated that a simple first-order die-off model can be applied to the decay of Enterococci bacteria for the sediment types. Overall, the study illustrated that the sediment has the potential to allow bacteria to survive for weeks in an aquatic environment rather than days as is typical in water. In addition, the relative organic and nutrient content of the sediment may not be as important to Enterococci die-off in the south shore of Lake Pontchartrain as initially thought.

\subsection{Implications for Modeling}

\subsubsection{Shoreline Water Quality Study}

The shoreline study provided evidence that the water quality in the south shore area has not improved sufficiently to recommend lifting the primary contact recreational advisory. In addition, the study showed that urban stormwater runoff pumped to the lake is responsible for the bacterial contamination that 
creates unsafe swimming conditions. However, it was observed that there are times when these sites are suitable for recreational use, e.g. after three days of dry weather following a significant pumping event. Overall, the study indicated that a beach management program is a suitable option for re-opening this valuable recreational resource. Development of the 3-D hydrodynamic and mass transport model as the forecasting tool for the program is justified, especially since wind and tide conditions are major considerations in terms of predicting which areas will be impacted by pumped stormwater.

The detection of an active, continuous source of pathogens that is not correlated to stormwater discharges at the IHNC indicates that the model must include this source. This was added to the model as a part of the calibration. It was treated as a stochastic input.

Finally, monitoring performed during wet weather conditions yields data that can be used to estimate typical dilutions achieved at recreational sites near the urban drainage canals. These dilution estimates can be used to check if model solutions are reasonable. Figure 5.8 shows the dilution curves developed for FC and DIN based on the field data. Dilution curves for FC include decay and can, therefore, be used to check the decay computed by the model. If the model is run without decay, i.e. for a tracer, the dilution curve of DIN can be used to check the model hydrodynamics. McCorquodale and Carnelos (2000) developed a simple regression model (Equation 5.3) for wide aspect weak plumes in cross-flow based on the shoreline field data and physical model data obtained through laboratory experiments using a hydraulic flume to study surface-buoyant plumes discharged perpendicular to a shoreline into a uniformdensity receiving water body with a cross-current flow. The regression model can be used for screening purposes during calibration of the 3-D model but should only be applied for canal outlet width to depth ratios (w/d) between 3 and 20. Dilution curves obtained from the physical model experiments and the regression model are also given in Figure 5.8.

$$
S_{\min }=\min \{1.0,[0.6+0.12(\xi / w)]\}
$$

where:

$$
\begin{aligned}
S_{\min } & =\text { minimum dilution } \\
\xi & =\text { distance along the plume trajectory, and } \\
w & =\text { width of drainage channel. }
\end{aligned}
$$




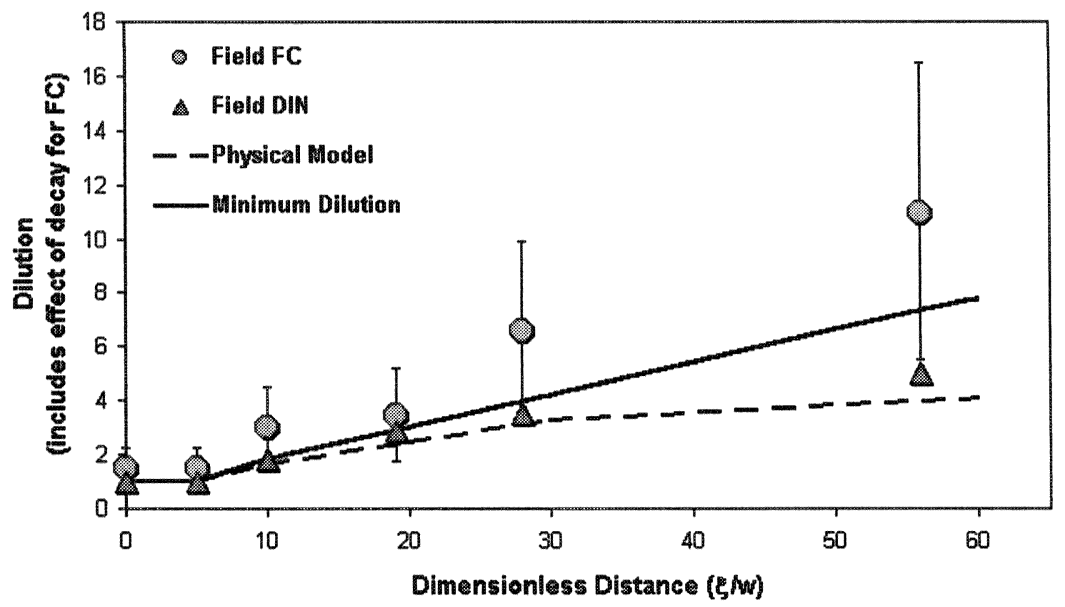

Figure 5.8 Field dilution curves for FC (including decay) and dissolved inorganic nitrogen (as a tracer) and model dilution curves for a physical laboratory model and minimum dilution regression model.

\subsubsection{Plume Tracking Study}

Six pump events for which both grid monitoring and in-canal monitoring were performed can be used for calibration and verification of the 3-D model by performing simulations for the wind, tide, discharge velocity and source concentration conditions specific to those events and comparing the solutions to the measurements made in the field during the events. Source concentration, i.e. the pumped stormwater, is taken as the geometric mean of the FC concentrations measured over the in-canal sampling period. Flow rates for the pumped discharges are estimated from the pump station records. Wind and tide data for a time period corresponding to the event are used to drive the wholelake model. Velocity and elevation data are extracted from the whole-lake solution beginning with the time corresponding to the pump start. That data, in addition to the pump volumes and bacteria source concentrations, are then used to set up initial conditions and drive the near-field model for a three-day run. Near-field solutions for bacteria can then be compared to the field measurements within the plume obtained during the grid monitoring. In addition, velocities computed by the model can be compared to velocities estimated from plume tracking data. Finally, the plume trajectories tracked by the drifter can be visually compared to the migrations of the plumes simulated by the model. 
Also, data obtained through the background monitoring, such as FC concentrations and salinity, characterizes ambient conditions of the lake that must be specified as initial conditions for the model.

\subsubsection{Laboratory Study}

The laboratory studies yielded essential information for the modeling component of the project. The fate and transport of pathogens (represented by FC as the pathogen indictor) in Lake Pontchartrain are calculated in the model through a two-step process: (i) transport and dilution and (ii) decay. For this purpose, the equations for correcting the rate constant for the effects of the environmental factors and computing the overall inactivation rate constant were incorporated into the model. Concentration is updated by solving the first-order decay equation (Equation 5.4) using the overall rate constant.

$$
C=C_{o} \cdot e^{(-k \cdot \Delta t)}
$$

where:

$$
\begin{aligned}
C_{o}= & \text { concentration calculated in the constituent transport } \\
& \text { and dilution step, } \\
C= & \text { corrected concentration after decay is applied, } \\
k= & \text { overall reduction rate constant, and } \\
\Delta t= & \text { model time step. }
\end{aligned}
$$

The model computes FC as per State regulations to assess health risk associated with recreational waters. However, most laboratory studies were not performed for FC. Since the studies also supported the literature stating that Enterococci is a more suitable indicator in brackish waters than $E$. Coli, the decay relationships applied in the model were developed using the laboratory results for Enterococci. The settling loss equation for Enterococci was also selected for the model since it provides more conservative estimates of the loss than the relationship for $E$. Coli.

The sediment study provided information that suggests that future modeling efforts would benefit from the inclusion of a sediment transport component. Lake Pontchartrain is a fairly shallow water body with highly winddriven circulation. Since the lake sediments were found to have high concentrations of bacteria and provide a hospitable environment for pathogens to persist, it is quite possible that significant levels of pathogens may be introduced into the water column through resuspension of bottom sediments. 


\subsubsection{Uncertainties in Field Data}

The variability of bacteria, e.g. FC counts, in the receiving water is a serious problem in the use and interpretation of field data. Variability can arise from the temporal and spatial randomness in the receiving waters and from uncertainties in the laboratory analyses. Uncertainty in a single data point can exceed one logcycle; however, if multiple samples and data points are available, the standard error in the mean is decreased as the inverse of the square root of the number of points (samples). In this study there were 5 stations with 360 data points each. These data were segregated to wet and dry classes based on samples taken within 3 days of rainfall higher than $12.5 \mathrm{~mm}(0.5 \mathrm{in})$ per day (pump station criterion) and samples taken outside this range. In comparing the log means of these two classes, the standard error in the mean of $\log \mathrm{FC}$ values is reduced from more than $1 \log$ cycle to less than 0.1 of a log cycle. Since the difference in the wet weather $\log \mathrm{FC}$ and the dry weather $\log \mathrm{FC}$ varies from approximately 0.2 to $1 \log$ cycle at all but one of the stations, it is possible to conclude that there is a significant difference between wet and dry weather data at these stations. At the station (IHNC) that had only a $0.1 \log$ cycle difference between wet and dry mean log values, it was not possible to conclude that there is a significant wet weather influence. The observed variability of the FC data in this study was compared with independent data that were collected by the Louisiana Department of Environmental Quality and the variability at a given station was found to be similar. The variability of multiple samples (up to 7) taken at the same station within a two hour period showed a one-log cycle geometric standard deviation which is consistent with the variability expressed as geometric standard deviation for all of the other stations. If sufficient data are collected the error in the mean of the $\log \mathrm{FC}$ values can be reduced to permit the identification of trends; however large error bounds must be used if the mean values are based on only a single sample. For model calibration purposes, the plume transport and mixing parameters were first adjusted using conventional pollutants (DIN in this study) and then the bacteria decay parameters were calibrated and validated using two sets of bacteria surveys.

\subsection{Conclusions}

Storm water runoff from a separated-sewer urban area can generate high pathogen indicators in the receiving waters. In this case study the suspected source of the contamination is cross-flow from surcharge sanitary sewers. 
Effective removal rate for pathogens from the water column depends on: temperature, salinity, light intensity and penetration, and sediment concentration and gradation. Field, laboratory studies and screening level models indicated that a period of 2 to $3 \mathrm{~d}$ after a runoff event was needed to reduce pathogen indicators to an acceptable level.

Drifter studies showed that the location of the plume was a function of the wind and the tide during the period just before the discharge and for 2 to 3 days afterward. This implies that the numerical model must consider the interaction of the whole lake with the near shore zone. In addition, the model should account for pathogen removal or re-introduction via fine grained suspended solids.

\section{References}

American Public Health Association, American Water Works Association, Water Environment Federation. (1998). Standard Methods for the Examination of Water and Wastewater (20th ed.).

Blumberg, A. F., and Mellor, G. L. (1987). A description of a three-dimensional coastal model. N. S. Heaps, (Ed.), Three Dimensional Coastal Ocean Models (pp. 1-16). Washington, D.C.: American Geophysical Union.

El-Sharkawi F., El-Attar, L., Gawad, A., and Molazem, S. (1989). Some environmental factors affecting survival of fecal pathogens and indicator organisms in seawater. Water Science and Technology, 21(1), 115-120.

Englande, A.J., Bradford, Henry B., and Jin, G. (1999). South Shore Water Quality Analysis and Outfall Plume Delineation (Phase II Report, Vol. I). New Orleans, LA: Dept. of Environmental Health Sciences, School of Public Health and Tropical Medicine, Tulane University.

Jin, G., Englande, A.J., Bradford, Henry, and Jeng, H.W. (2000, March). Appropriate Indicators for Recreational Waters: Lake Pontchartrain Basin Case Study. Paper presented at the Water Environment Federation conference, New Orleans, LA.

Liltved, H. and Landfald, B. (2000). Effect of high intensity light on ultraviolet irradiated and non-irradiated fish pathogenic bacteria. Water Research, 34(2), $481-486$.

Louisiana Department of Environmental Quality. (1999). Surface Water Quality Standards (Title 33, Environmental Quality, Part IX, Water Quality Regulations, Chapter 11).

Louisiana Department of Health and Human Resources. (1982). Lake Pontchartrain Bacterial Pollution Study: Executive Summary (p.37). New Orleans, LA: Office of Health Services and Environmental Quality, Louisiana Department of Health and Human Resources. 
McCorquodale, J.A., Hannoura, A.A and Carnelos, Susanne. (2000). Urban Storm and Waste Water Outfall Modeling (Final Project Report submitted to U.S. Environmental Protection Agency). New Orleans, LA: Urban Waste Management Research Center, College of Engineering, University of New Orleans.

Mueller, John A., and Thomann, Robert V. (1987). Principles of Surface Water Quality Modeling and Control (p. 236). New York, NY: Harper \& Row Publishers.

Sewerage and Water Board of New Orleans. (1990, April). How It Began, The Problems It Faces, The Way It Works, The Job It Does (pamphlet). New Orleans, LA: Sewerage and Water Board of New Orleans.

U.S. Environmental Protection Agency. (1986). Ambient water quality criteria for bacteria - 1986 (EPA 440/5-84-002). Washington, D.C.: U.S. Environmental Protection Agency.

U.S. Environmental Protection Agency. (1986). Test Methods for Evaluating Solid Waste, Physical/Chemical Methods (USEPA, SW-846, 3rd ed., Method 9081). Washington, D.C.: U.S. Environmental Protection Agency.

Williams, Leslie. (2000, June 9). Divers Will scour Bottom for Debris at Lincoln Beach (Orleans Section: Metro, p. B08). New Orleans, LA: The Times-Picayune.

Yang, L., Chang W.S. and Huang, M.L. (2000). Natural disinfection of wastewater in marine outfall fields. Water Research, 34(3), 743-750.

Yu, Ye. (1995). Urban Stormwater Quality Analysis. Master's thesis (p.103), Graduate School, University of New Orleans, New Orleans, LA. 